\title{
RESEARCH STUDIES ON EVALUATION OF PHYTOCHEMICAL AND ANTIBACTERIAL ACTIVITY OF COLD ETHANOIC EXTRACT OF EUCALYPTUS OIL
}

\author{
Dr P. Rajasulochana ${ }^{1}$, Pavitra $^{2}$ \\ ${ }^{1}$ Professor, Dept. of Geneic Engineering, Bharath Institute of Higher Education and Research, Bharath University, Chennai, \\ India \\ ${ }^{2}$ Student, Dept. of Genetic Engineering, Bharath Institute of Higher Education and Research, Bharath University, Chennai, India
}

\begin{abstract}
Medicinal plants which have antimicrobial compounds act against various pathogens. Myrtle family have different species. Eucalyptus is one among the myrtle family. Eucalyptus have different antimicrobial compounds. The plant grows well in many countries. This fast growing plant have different parts, each part has its own significant medicinal values lik timber, pulpwood, and different essential oils. Our research study showed phytochemical composition and antibacterial activities of eucalyputs leaves. The sample of eucalyptus is collected in the powder form. The eucalyptus powder is mixed into a cold ethanol and dry in a hot air oven. The dried extract was swapped and measured. Weighted $2.096 \mathrm{~g}$ respectively and then the extract is used for phytochemical analysis and for quantitative analysis and then for antibacterial assay The results of this study suggest that the different concentrations of eucalyptus with various concentrations showed potential antibacterial activity.
\end{abstract}

Keywords: Eucalyptus, pathogenic organism, phytochemical composition, antibacterial activity

\section{Introduction}

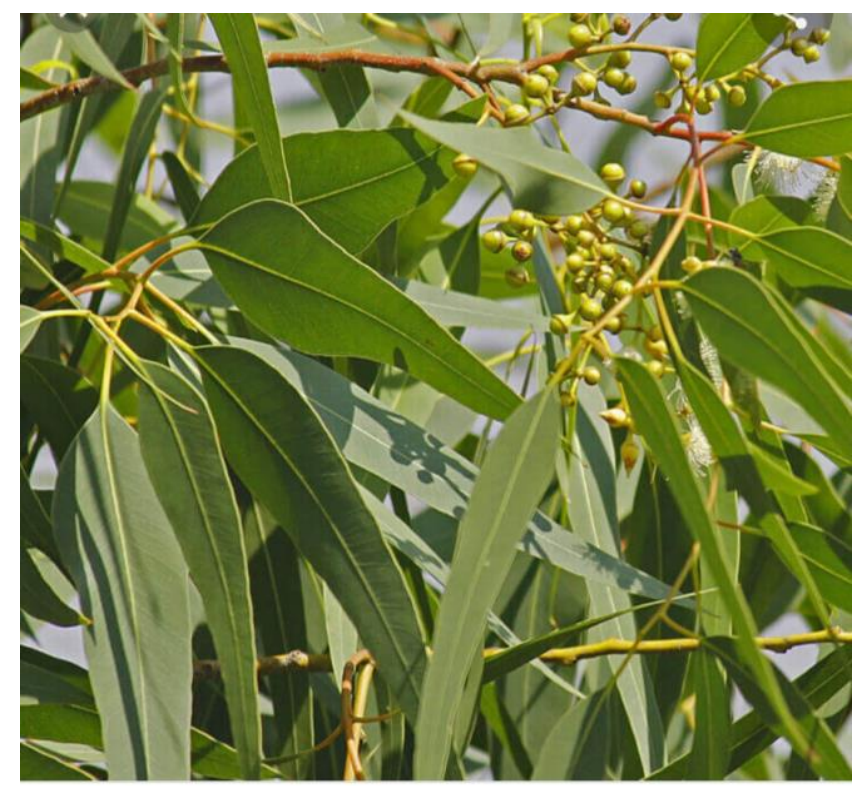

Fig : Eucalyptus leaves

The Australia originated plant eucalyptus grow in all areas and they are cultivated in different climates. Based on the literature these leaves has essential oils, which showed different antimicrobial activities. Tunisia etal.,1957 introduced nearly 120 species of eucalyptus, used for fire wood and mine wood ,against erosion also. Very less studies reported on this oils and its bio activity at global level. Tunisia etal 2010,11 reported first about this oil and its antibacterial activity. Eucalyptus oil showed antiviral activity also., which will useful to treat influenza.Cowam etal 1999studies showed the value of phytomedicins, which will useful to treat different viral infection.

K.D. Hill \& L.A.S. Johnson 2012 performed invitro studies of antimicrobial and antioxidant activates of the phenolic extract of eucalyptus leaves.

2. Materials And Methods:

Objectives:

1.sample collection

2.prepration of extraction

3.primary phytochemical analysis

4. sequential extraction

5.antibacterial assay.

3. Sample Collection:

Samples of eucalyptus is collected in the form of powder. eucalyptus was dried in the sunlight until they dry and then grinded into powdered form. 


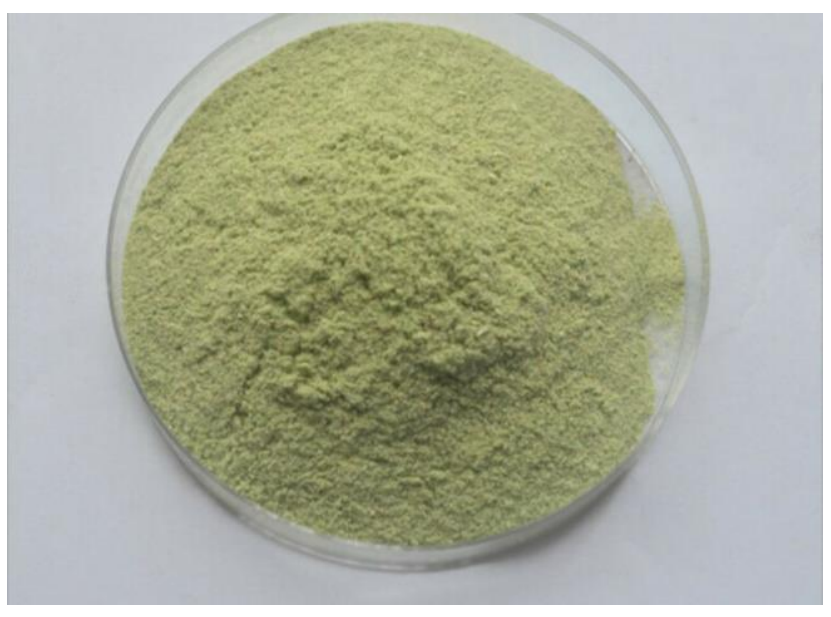

Fig: shows the sample in powder form

\section{SEQUENTIAL EXTRACTION:}

The secondary metabolites had extracted from the sample using high polar solvent sequentially. Methanol $\left(\mathrm{C}_{2} \mathrm{H}_{5} \mathrm{OH}\right)$ is taken as high polar solvent. The sample is kept in a conical flask. And then kept in the hot extraction method. After kept in the hot air oven until it dry. After evaporation the dried extract were scrapped and measured. Then the extract was weighed about $2.096 \mathrm{~g}$ respectively. The extract is stored separately.

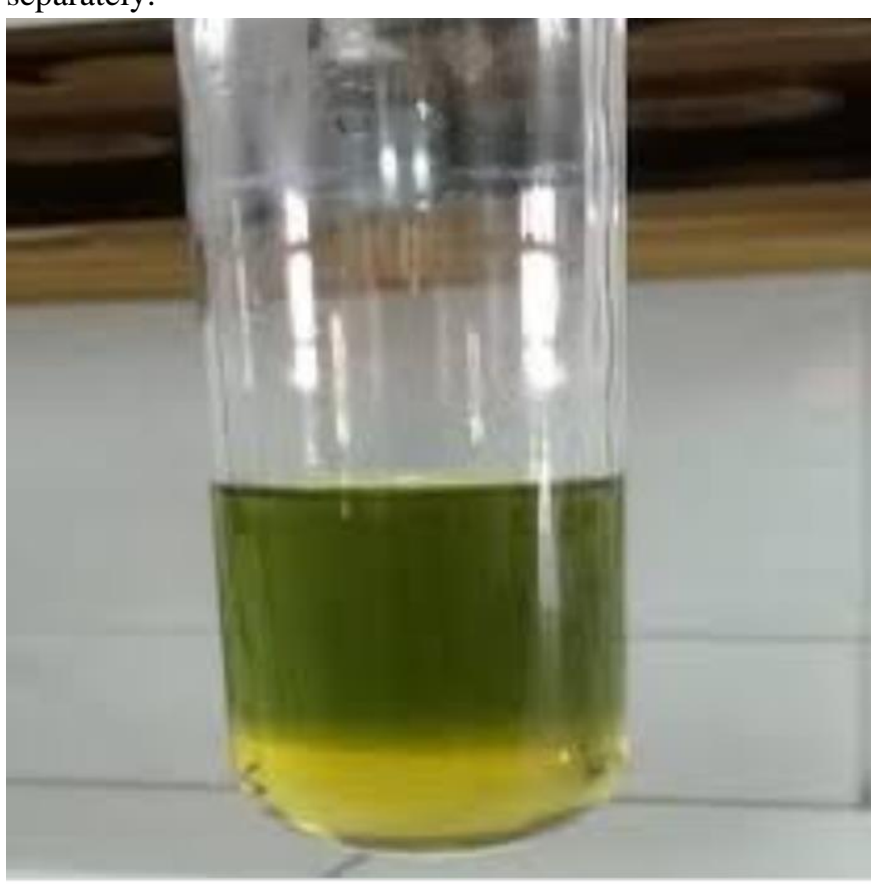

Extreaction of sample

\section{Phytochemical Analysis:}

carbohydrates,tannins,saponins,flavonoids, Alkaloids, Quinine, Glycosides, Cardiac glycosides, Terpenoids, Phenols, Coumarins, Steroids and Phytosteroids, Phlobatannins, Terpenoids, Anthraquinones in extract was identified with Indian standard methods.

\section{Antibacterial Assay:}

The plant pathogenic bacteria is isolated from the spoiled fruit or vegetables and serially diluted and isolated. The isolated bacteria were cultured by mat culturing technique and the wells are punched in agar plates and the plant extract of different concentration was poured in the wells for zone of inhibition.

\section{Results And Discussion}

Qualitative estimation of primary metabolites. Using standard methods Primary phytochemical analysis of various metabolites was carried out and observed various changes in study sample.

Table: This table showed qualitative estimation of primary metabolites in sample.

\begin{tabular}{|l|c|c|}
\hline \multicolumn{1}{|c|}{ TEST } & $\begin{array}{c}\text { OBSERVATION } \\
\text { (COLOUR) }\end{array}$ & CONFORMATION \\
\hline Carbohydrates & Brown & Absence \\
\hline Tannins & Light Black & Absence \\
\hline Saponins & No foam & Absence \\
\hline Flavonoids & Yellow & Presence \\
\hline Quinine & Two Layers & Absence \\
\hline Glycosides & Yellow & Absence \\
\hline $\begin{array}{l}\text { Cardic } \\
\text { Glycosides }\end{array}$ & Two White & Absence \\
\hline Terpenoids & Layers & Presence \\
\hline Phenols & Bluish Green & Presence \\
\hline Coumarins & Yellow & Absence \\
\hline $\begin{array}{l}\text { Steroids } \\
\text { andPhytosteroids }\end{array}$ & Two Layers & Absence \\
\hline Phlobatannins & Yellow & Absence \\
\hline Anthraquinones & Yellow & \\
\hline
\end{tabular}

\section{Quantitative Analysis:}

\section{ESTIMATION OF TOTAL PHENOLIC CONTENT:}

Different aliquots [sample and galic acid] (0.2 to $1.0 \mathrm{ml})$ were pipetted into test tubes. $0.5 \mathrm{ml}$ of Folin'sCiocalteau reagent was added, then the test tubes mixed thoroughly after adding with $2 \mathrm{ml}$ of $35 \%$ of $\mathrm{Na} 2 \mathrm{CO} 3$ solution.

Place the tubes in the boiling water bath for exactly one min, cool and measure the absorbance at $650 \mathrm{~nm}$ against the reagent blank. Prepare a standard curve using different concentrations of catechol.

CONCENTRATION AND ABSORBANCE OF GALIC ACID FOR STANDARD:

\begin{tabular}{|c|c|c|}
\hline SAMPLE & Corcentration & Absorbance \\
\hline 1 & 0.2 & 0.046 \\
\hline 2 & 0.4 & 0.084 \\
\hline
\end{tabular}




\begin{tabular}{|l|l|l|}
\hline 3 & 0.6 & 0.104 \\
\hline 4 & 0.8 & 0.135 \\
\hline 5 & 1.0 & 0.134 \\
\hline
\end{tabular}

\section{CONCENTRATION AND ABSORBANCE OF} EUCALPTUS:

\begin{tabular}{|l|l|}
\hline Concentration & Absorbance \\
\hline 0.2 & 0.149 \\
\hline 0.4 & 0.325 \\
\hline
\end{tabular}

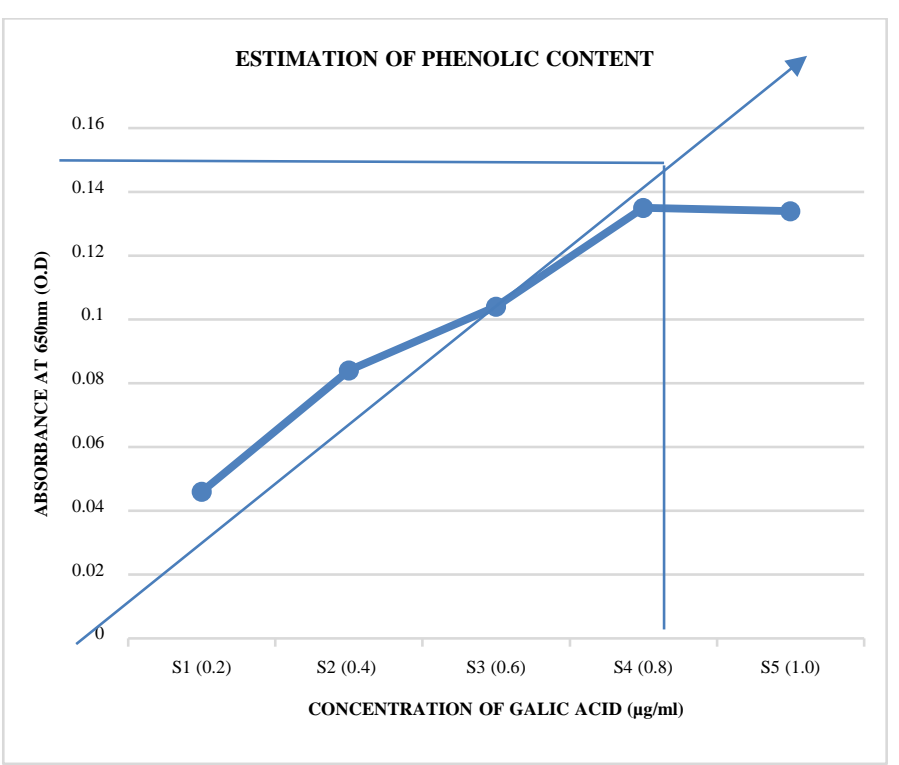

\section{CALCULATION:} content

$0.2 \mathrm{mg} / \mathrm{ml}$ of sample contains $=8.6 \mu \mathrm{g}$ of phenol

For $0.1 \mathrm{mg}$ of sample $=4.3 \mu \mathrm{g}$ of phenol $1000 \mathrm{ug}$ of sample contains $=43 \mu \mathrm{g}$ of phenol. $1 \mathrm{mg}$ of eucalyptus contains $43 \mu \mathrm{g}$ of phenol.

\section{ESTIMATION OF FLAVONOIDS:}

Add $0.5 \mathrm{ml}$ sample to test tube containing $1.25 \mathrm{ml}$ of distilled water, $0.075 \mathrm{ml}$ of $5 \%$ sodium nitrite solution, allowed to stand for $5 \mathrm{mins}$. $0.15 \mathrm{ml}$ of $10 \%$ aluminum chloride. $6 \mathrm{~min} 0.5 \mathrm{ml}$ of $1 \mathrm{M} \mathrm{NaOH}$ was added and mixture was diluted with another $0.275 \mathrm{ml}$ of distilled water. The absorbance of mixture at $510 \mathrm{~nm}$ was measured immediately (Kim etal.2003).

\section{CONCENTRATION AND ABSORBANCE OF} QUERCETIN FOR STANDARD:

\begin{tabular}{|c|c|c|}
\hline Sample & Concentration & Absorbance \\
\hline 1 & 0.1 & 0.013 \\
\hline 2 & 0.2 & 0.026 \\
\hline 3 & 0.3 & 0.031 \\
\hline 4 & 0.4 & 0.038 \\
\hline 5 & 0.5 & 0.075 \\
\hline
\end{tabular}

\section{CONCENTRATION AND ABSORBANCE OF EUCALYPTUS:}

\begin{tabular}{|c|c|}
\hline Concentration & Absorbance \\
\hline 0.2 & 0.002 \\
\hline 0.4 & 0.001 \\
\hline
\end{tabular}

\section{ESTIMATION OF FLAVONOIDS}

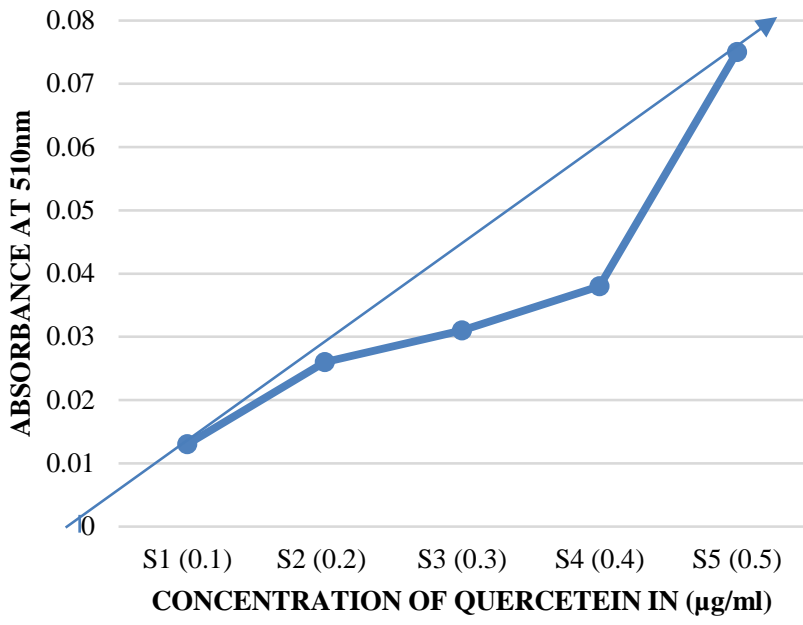

Above Graph represented the flavonoids estimation.

\section{CALCULATION:} flavonoids

$0.1 \mu \mathrm{g}$ of eucalyptus sample contains $0.2 \mu \mathrm{g}$ of

$1 \mu \mathrm{g}=0.2 \mu \mathrm{g}$

$1 \mathrm{mg}=200 \mu \mathrm{g}$ of flavonoids

$1 \mathrm{mg}$ of eucalyptus contains $200 \mu \mathrm{g}$ of flavonoids

\section{ANTIBACTERIAL ASSAY:}

Mat culture techniques used to culture the pathogenic bacteria, isolated from spoiled plant materials, and identified antibacterial activity of eucalyptus oil using agar plate method 


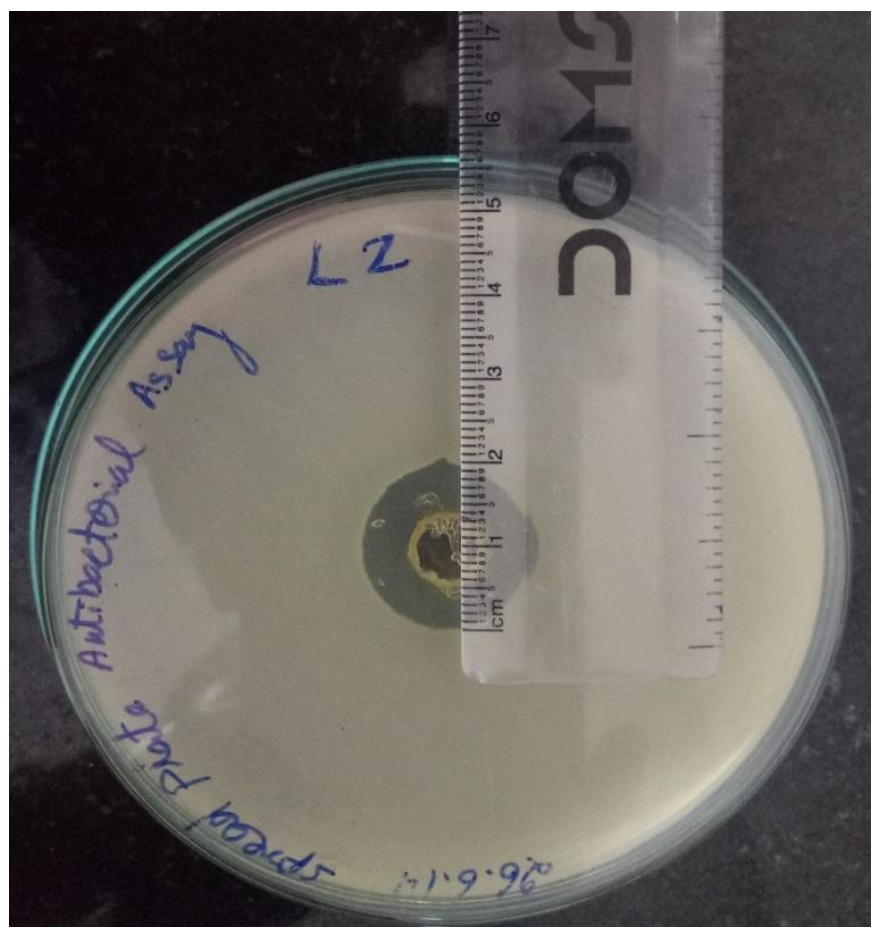

zone of the inhibition of pathogenic bacteria(Pseudomonas)

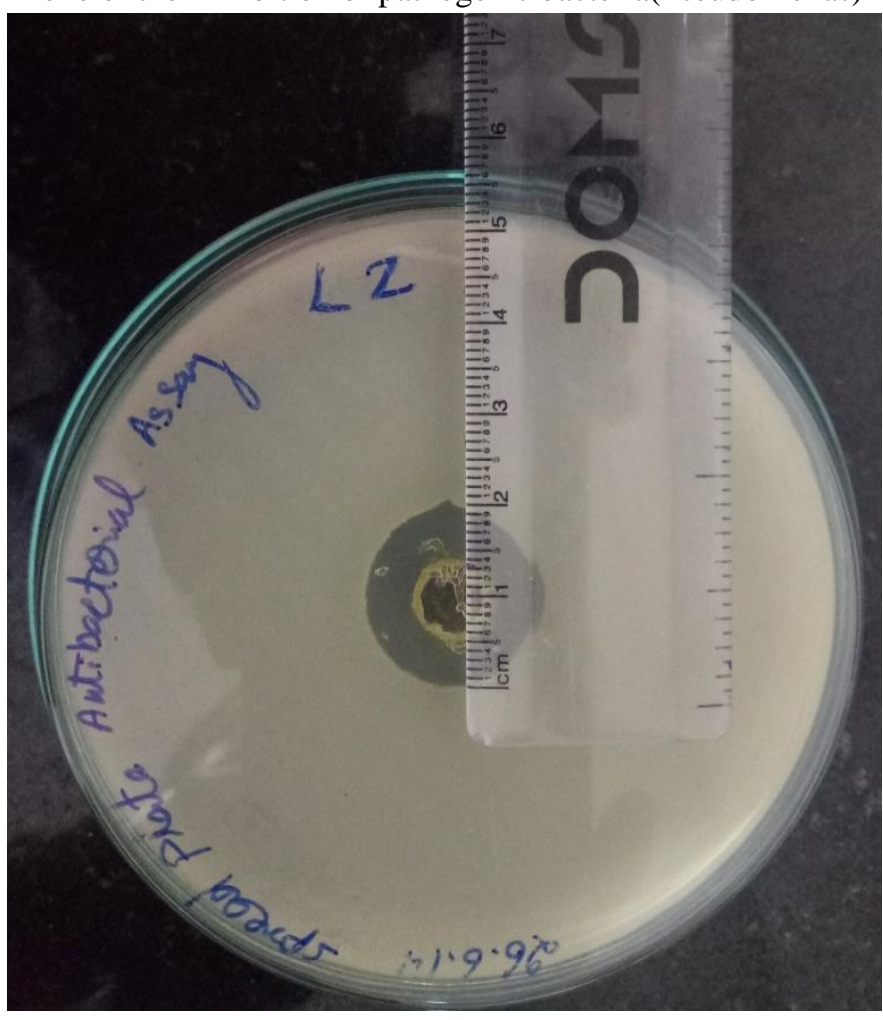

zone of the inhibition of pathogenic bacteria(Ervinia)

\section{CONCLUSION:}

The antibacterial activity of eucalyptus over the bacteria was $20.00 \mathrm{~mm}$ average zone of inhibition. This indicates that eucalyptus contains the antibacterial activity. This study also indicates the phytochemical composition and antibacterial activities of eucalyptus. The antibacterial activity of the ethanolic eucalyptus extract had a strong antibacterial activity against bacteria like Pseudomonas and Ervinia.

\section{References}

[1] Tesh RB. The genus Phlebovirus and its vectors. Annu Rev Entomol 1988; 33: 169-181.

[2] Sabin AB, Philip CB, Paul JR. Phlebotomus (pappataci or sandfly) fever: a disease of military importance; summary of existing knowledge and preliminary report of original investigations. JAMA 1944; 125: 603-606.

[3] Liu DY, Tesh RB, Travassos Da Rosa AP et al. Phylogenetic relationships among members of the genus Phlebovirus (Bunyaviridae) based on partial $\mathrm{M}$ segment sequence analyses. J Gen Virol 2003; 84: 465473.

[4] Mith H, Dure' R, Delcenserie V, Zhiri A, Daube G, Clinquart A. Antimicrobial activities of commercial essential oils and their components against food-borne pathogens and food spoilage bacteria.Food Sci Nutr. 2014;2:403-416.

[5] Cocolin L, Rantsiou K, Iacumin L, Cantoni C, Comi G. Direct identification in food samples of Listeria spp. and Listeria monocytogenes by molecular methods. Appl Environ Microbiol. 2002; 68:6273-6282.

[6] Morvan A, Moubareck C, Leclercq A, et al. Antimicrobial resistance of Listeria monocytogenes strains isolated from humans in France. Antimicrob Agents Chemother. 2010;54:2728-2731.

[7] Brooker MI, Keing DA: Field guide to Eucalyptus (2nd ed.). In Bloomings Book. Northern Australia: Melbourne; 2004.

[8] Dr. P. Rajasulochana, Saby, ANTIBACTERIAL ACTIVITY OF MULLATHA AND CHITTAMRUTU, International Journal Of Pharmacy \& Technology, March-2016, 8 (1), pp: 10518-10522.

[9] Dr. P. Rajasulochana and Saby, identification of anticanerous activity of mullatha (annona muricata) and chittamruthu (tinospora cordifolia), world journal of pharmacy and pharmaceutical sciences, 2016, Volume 5, Issue 03, 667-674. ISSN 2278 - 4357.

[10] ShriVishalini R. and P. Rajasulochana, a novel approach to synthesis and characterization of silver nano particles of feverfew seeds, Journal of Chemical and Pharmaceutical Research, 2016, 8(1):690-697, ISSN: 0975-7384. 
